\title{
NAB2/STAT6 Fusion Protein
}

National Cancer Institute

\section{Source}

National Cancer Institute. NAB2/ST AT6 Fusion Protein. NCI Thesaurus. Code C122820.

A fusion protein that is encoded by the NAB2/STAT 6 fusion gene. This protein contains the $\mathrm{N}$-terminal early growth response (EGR)-binding domain of NGFI-A-binding protein 2 fused to part of signal transducer and activator of transcription 6 protein that includes its DNA-binding transcriptional activation domain. 